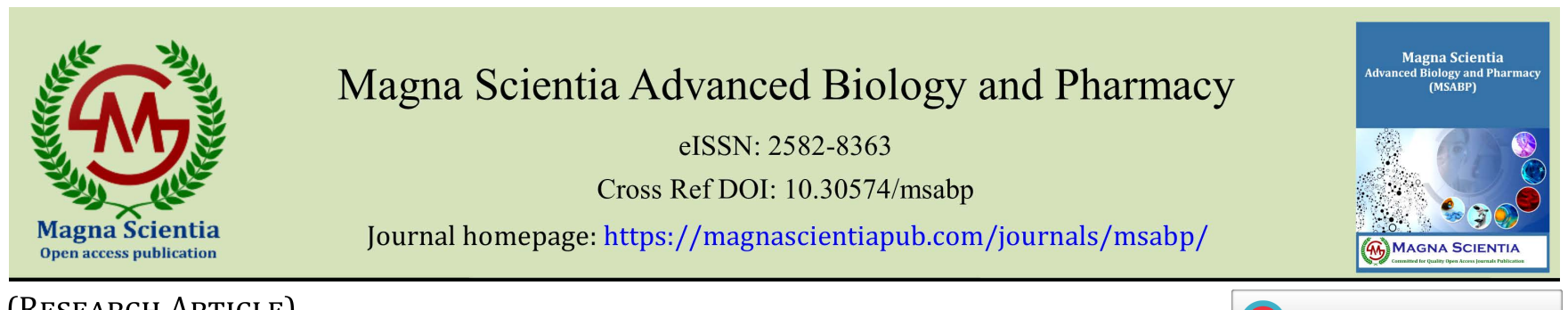

(RESEARCH ARTiClE)

\title{
Levels of heavy metals in pelagic and benthic fish species in river Nun at Amassoma, Bayelsa State, Nigeria
}

\author{
Koru Joe Alagoa $1{ }^{*}$, Jeremiah Akpodoite Yabefa ${ }^{2}$ and Erepamo Jonathan Yowei 1 \\ ${ }^{1}$ Department of Biological Sciences, Niger Delta University, Amassoma, Bayelsa State, Nigeria. \\ ${ }^{2}$ Bayelsa State Polytechnic Aleibiri, Bayelsa State, Nigeria.
}

Magna Scientia Advanced Biology and Pharmacy, 2021, 03(02), 015-021

Publication history: Received on 11 August 2021; revised on 17 September 2021; accepted on 19 September 2021

Article DOI: https://doi.org/10.30574/msabp.2021.3.2.0044

\begin{abstract}
The heavy metals content in three fish species from River nun Amassoma axis was investigated. This was done in order to gauge the concentration of heavy metals in fish tissues and to estimate the safety of consuming these fish species on human health. Three species (pelagic and benthic fishes) were collected from local fishermen at the landing jetty and analyzed for heavy metals in the soft tissues using standard procedures. The heavy metals investigated are Cadmium (Cd), Nickel (Ni), Lead ( $\mathrm{Pb}$ ) and Chromium (Cr). Result indicates that $\mathrm{Cd}>\mathrm{Ni}>\mathrm{Pb}>\mathrm{Cr}$ in the fish samples analyzed while Chrysichthys auratus showed the greatest abundant characteristics of $\mathrm{Cr}, \mathrm{Pb}, \mathrm{Ni}, \mathrm{Cd}$. There was no significant difference $(\mathrm{P}>0.05)$ in concentrations of $\mathrm{Cr}$ and $\mathrm{Ni}$ for all fish species. However, the results showed that there is a significant difference $(\mathrm{P}<0.05)$ in $\mathrm{Pb}$ concentration between Chrysichthys auratus, Chrysichthys aluuensis and Petrocephalus bane bane. $\mathrm{Cd}$ concentration in the fish species reveal that there is a significant difference $(\mathrm{P}<0.05)$ between Chrysichthys auratus and Petrocephalus bane bane but no significant difference ( $>0.05)$ between Chrysichthys auratus and Chrysichthys aluuensis and between Chrysichthys aluuensis and Petrocephalus bane bane Heavy metal in the fish species showed that Chrysichthys auratus $>$ Chrysichthys aluuensis $>$ Petrocephalus bane bane. All metal characteristics were lower than the suggested WHO permissible limit. Benthic fish species have a greater heavy metal concentration than the pelagic fishes. Based on the observation from this study, the continuous and sustained consumption of Chrysichthys auratus and indeed benthic fish species possess a higher risk to health, while Cd poisoning in fish is most culpable of pollution in River Nun at Amassoma. axis.
\end{abstract}

Keywords: Heavy Metal; Pelagic; Benthic; Fish; River Nun; Amassoma

\section{Introduction}

The efforts of artisanal fishers contribute greatly to meeting fish demands in Nigeria. Little catches here and there add to the National pool of capture fisheries. The remaining gap of our fish needs must be met by importation and culture fisheries. In the River nun at Amassoma axis, the practice of fishing and landing fish catch at the Jetties is a daily ritual. In an attempt to meet our requirement for protein needs, buyers scramble for the few available catch. A catch that decreases daily despite increasing efforts due to pollution. Fish serves as an important source of providing the muchrequired dietary protein for sustenance of human health. However, the presence of heavy metals in fish can invalidate their beneficial effects. Therefore, the consumption of fish from the river nun must be viewed and scrutinized to determine its health implications. Fish containing heavy metals from polluted environments have devastating consequences on human health. Aquatic ecosystems are contaminated with heavy metals entering it and are stored in fish and other aquatic organisms through the processes of bioaccumulation and biological magnification via the food chain and accumulates to reach a substantially high level [1].

\footnotetext{
${ }^{*}$ Corresponding author: Koru Joe Alagoa

Department of Biological Sciences, Niger Delta University, Amassoma, Bayelsa State, Nigeria.

Copyright $(2021$ Author(s) retain the copyright of this article. This article is published under the terms of the Creative Commons Attribution Liscense 4.0.
} 
As fish constitutes the major protein source of people living in Amassoma, there is a grave need to evaluate some commercial fish species harvested from the river nun and consumed in the area for their heavy metal characteristics. This will reveal the safety of consuming such fishes, reveal the environmental health status of the river and serve purposes for environmental monitoring and law enforcement.

\section{Material and methods}

\subsection{Description of Study Area}

The study area is the River Nun, along the Amassoma community in Southern-Ijaw Local Government Area of Bayelsa State, Nigeria. The river serves as a major source of water supply to the inhabitants for transportation, fishing, artisanal dredging and dumping of waste.

\subsection{Study Organism}

The three fish species; Petrocephalus bane bane (Pelagic fish), Chrysichthys aluuensis and Chrysichthys auratus (Benthic fishes) were selected for the study. They were purchased early in the morning from local fishers arriving the shore (Jetty) after overnight fishing.

\subsection{Sample Collection and Transport}

60 fish samples (20 each from three species) were collected from fishers at the shores of River-Nun, Amassoma water front (Jetty). They were brought in plastic buckets to the Chemical Science Laboratory of the Niger Delta University, Amassoma, Bayelsa State.

\subsection{Sample Preparation}

Fish samples were brought to the laboratory in pristine conditions. They were washed under a running tap, drained, dried and the muscular tissues from dorsal, abdominal and tail regions of each fish were taken out and homogenized. Four grams of the homogenized muscles (without skin) were taken from each specimen and placed in $300 \mathrm{ml}$ kjeldahl digestion tubes. A digestion mixture containing $6.0 \mathrm{ml}$ of high purity nitric acid (Merck), $2 \mathrm{ml}$ of hydrochloric acid (10 M) and $4 \mathrm{ml}$ of hydrogen peroxide (35\%) were then added to each tube.

The samples were then heated to $130^{\circ} \mathrm{C}$ by kjeldahl heating digester until clear solutions were obtained. The digested portions were filtered through Whitman filter paper (No. 42) and diluted to a final volume of $50 \mathrm{ml}$ using deionized water. The analytical technique used to determine heavy metal levels in all samples was thermos-element Solar S4 Atomic Absorption Spectroscopy (International Equipment Trading Ltd, USA).

At each step of the digestion processes, acid blanks (laboratory blank) were prepared in order to ensure that the samples and chemicals used were not contaminated. They were analyzed using the atomic absorption spectrophotometry before the samples and their values were subtracted to ensure that the equipment read only the exact values for each heavy metal. Each set of digestion has its own acid blank and was corrected by using its blank.

\subsection{Atomic Absorption Spectroscopy}

This technique makes use of absorption spectrometry to assess the concentration of trace heavy metal in the sample. The digested fish samples were then subjected to atomic absorption spectroscopy analysis for the various trace metals. The analysis was done with acetylene/ air gas combination at various lamp current and wavelengths.

\subsection{Statistical Analysis (Data Analysis)}

Means and standard deviation were calculated for all metal parameters for the experimental fish samples. Analysis of variance (ANOVA) was used at the 95\% probability level to compare means for the heavy metal characteristics of the different fish species from River-Nun, Amassoma, Bayelsa State. Turkey HSD post Hoc test was performed to separate means and determine the degree of differences or interrelated of the means. Correlation analysis was employed to measure the degree of variability and relatedness of the heavy metal characteristics. SPSS® (version 20.0) software was employed to aid in the data analysis procedure. 


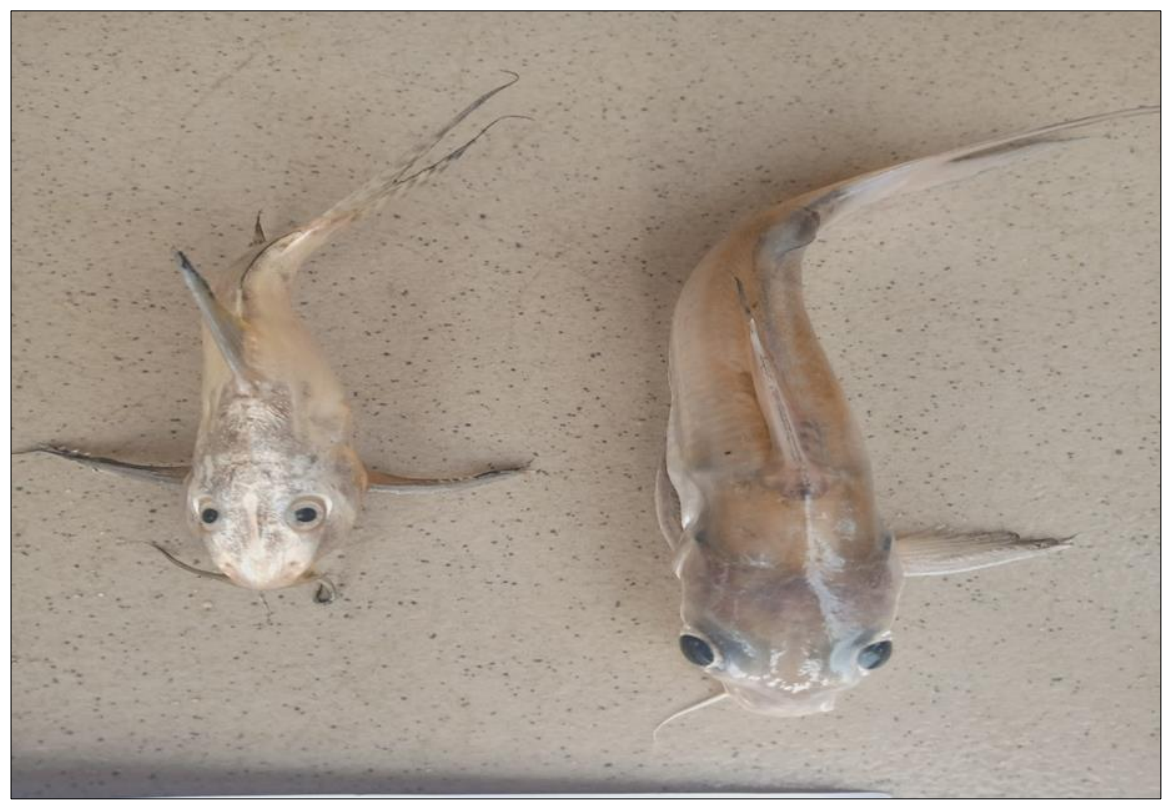

Plate 1 Picture of Chrysichthys aluuensis and Chrysichthys auratus from River-nun

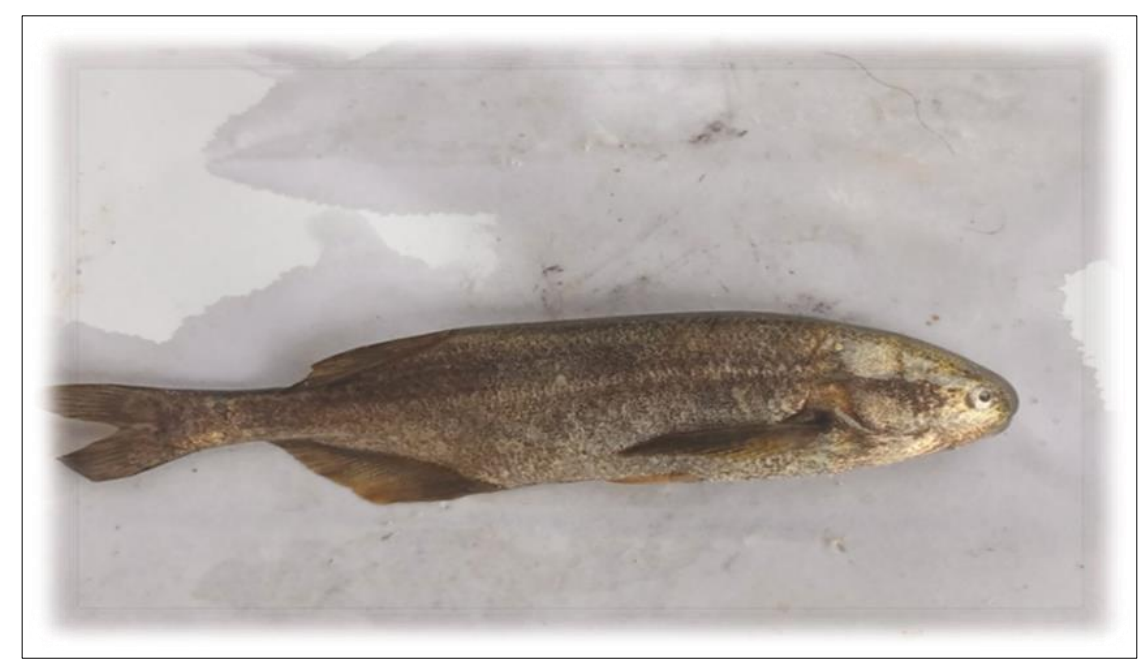

Plate 2 Picture of Petrocephalus bane bane

\section{Results and discussion}

The result of the study is displayed in Table 1 and Figures $1-5$.

The characteristic of the fish species used in this study indicate that Petrocephalus bane bane is a pelagic herbivore or omnivore whereas Chrysichthys auratus and Chrysichthys aluuensis are benthic carnivores. Heavy metal presentation in all the fish species reveal that $\mathrm{Cd}>\mathrm{Ni}>\mathrm{Pb}>\mathrm{Cr}$.

There is no significant difference $(\mathrm{P}>0.05)$ in $\mathrm{Cr}$ concentration between the three fish species. However, $\mathrm{Cr}$ concentration in the three fish species indicate that Chrysichthys auratus $>$ Chrysichthys aluuensis $>$ Petrocephalus bane bane. There is a significant difference $(\mathrm{P}<0.05)$ between Chrysichthys auratus, Chrysichthys aluuensis and Petrocephalus bane bane in $\mathrm{Pb}$ concentration. Levels of $\mathrm{Pb}$ reveal that Chrysichthys auratus $>$ Chrysichthys aluuensis $>$ Petrocephalus bane bane. (Table 1)

There is also no significant difference $(\mathrm{P}>0.05)$ in Ni concentration between the three fish species. 
However, $\mathrm{Cr}$ concentration in the three fish species indicate that Chrysichthys auratus $>$ Chrysichthys aluuensis $>$ Petrocephalus bane bane. Cd concentration in the fish species reveal that there is a significant difference $(\mathrm{P}<0.05)$ between Chrysichthys auratus and Petrocephalus bane bane but no significant difference (P>0.05) between Chrysichthys auratus and Chrysichthys aluuensis and between Chrysichthys aluuensis and Petrocephalus bane bane (Table 1).

The results of this study are in disagreement with the findings of Abdallah [2] and Nweeze et al. [3] in which pelagic fish (omnivorous/herbivore) recorded higher metals concentrations than the benthic fish (carnivore).

Table 1 Heavy metal concentrations in different fish species

\begin{tabular}{l|l|l|l|l|l|}
\hline S/N & \multicolumn{2}{c}{ Fish Species } & \multicolumn{1}{c}{ Cr } & Pb & Ni \\
\hline $\mathbf{1}$ & Petrocephalus bane bane & $0.017^{\mathrm{a}} \pm .015$ & $0.0056^{\mathrm{a}} \pm .0045$ & $0.03^{\mathrm{a} \pm .026}$ & $0.123^{\mathrm{a} \pm .077}$ \\
\hline $\mathbf{2}$ & Chrysichthys aluuensis & $0.036^{\mathrm{a}} \pm .037$ & $0.043^{\mathrm{b}} \pm .0153$ & $0.26^{\mathrm{a} \pm .163}$ & $0.43^{\mathrm{ab} \pm .098}$ \\
\hline $\mathbf{3}$ & Chrysichthys auratus & $0.036^{\mathrm{a}} \pm .021$ & $0.086^{\mathrm{b}} \pm .0153$ & $0.37^{\mathrm{a} \pm .320}$ & $0.526^{\mathrm{b} \pm .241}$ \\
\hline
\end{tabular}

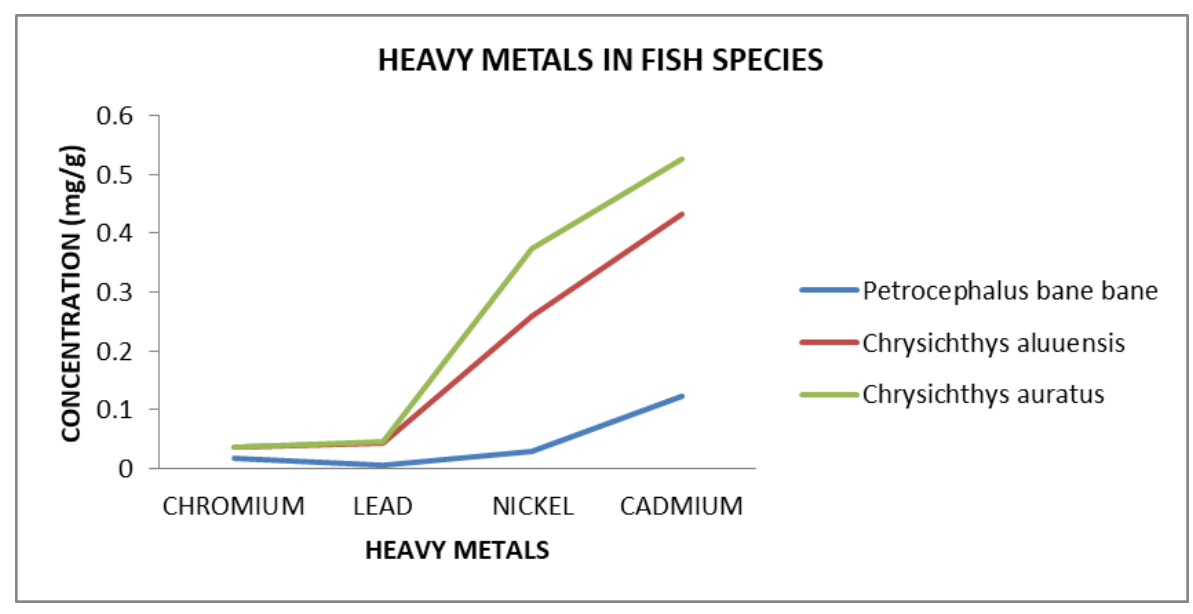

Figure 1 Heavy metal concentrations in different fish species

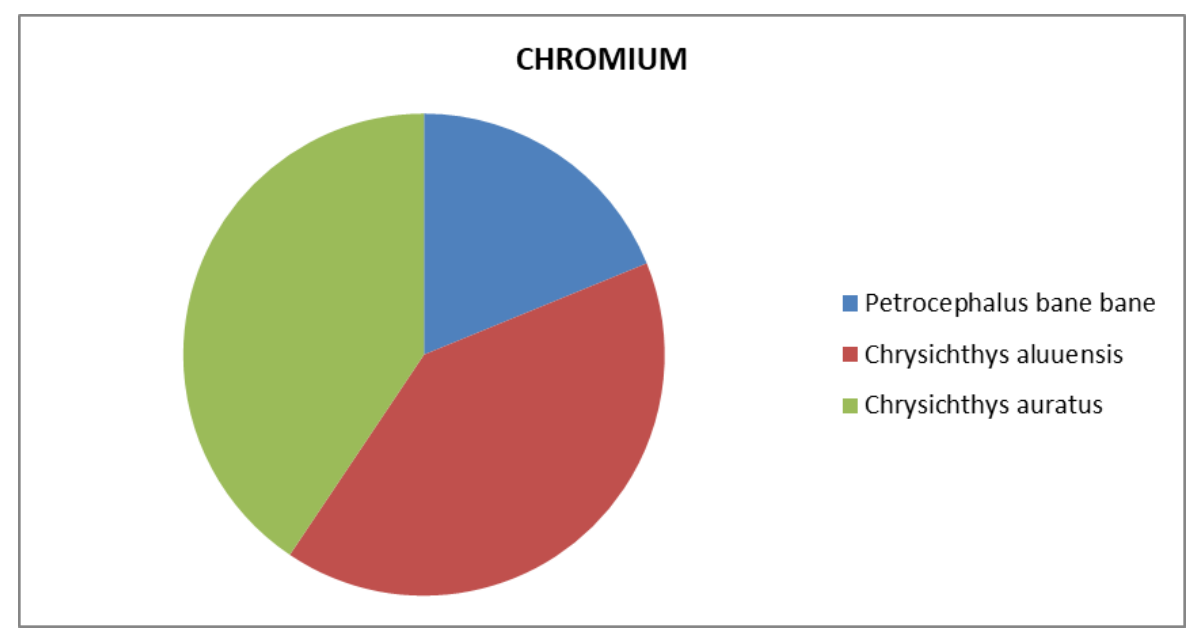

Figure 2 Chromium concentrations in different fish species 
Magna Scientia Advanced Biology and Pharmacy, 2021, 03(02), 015-021

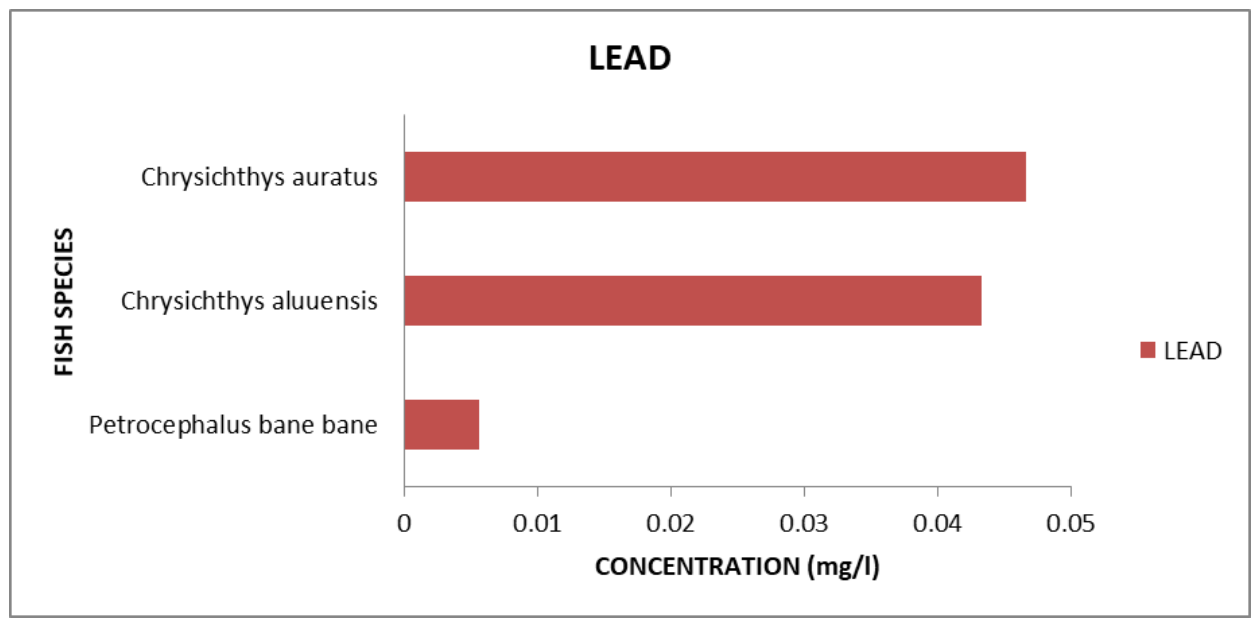

Figure 3 Lead concentrations in different fish species

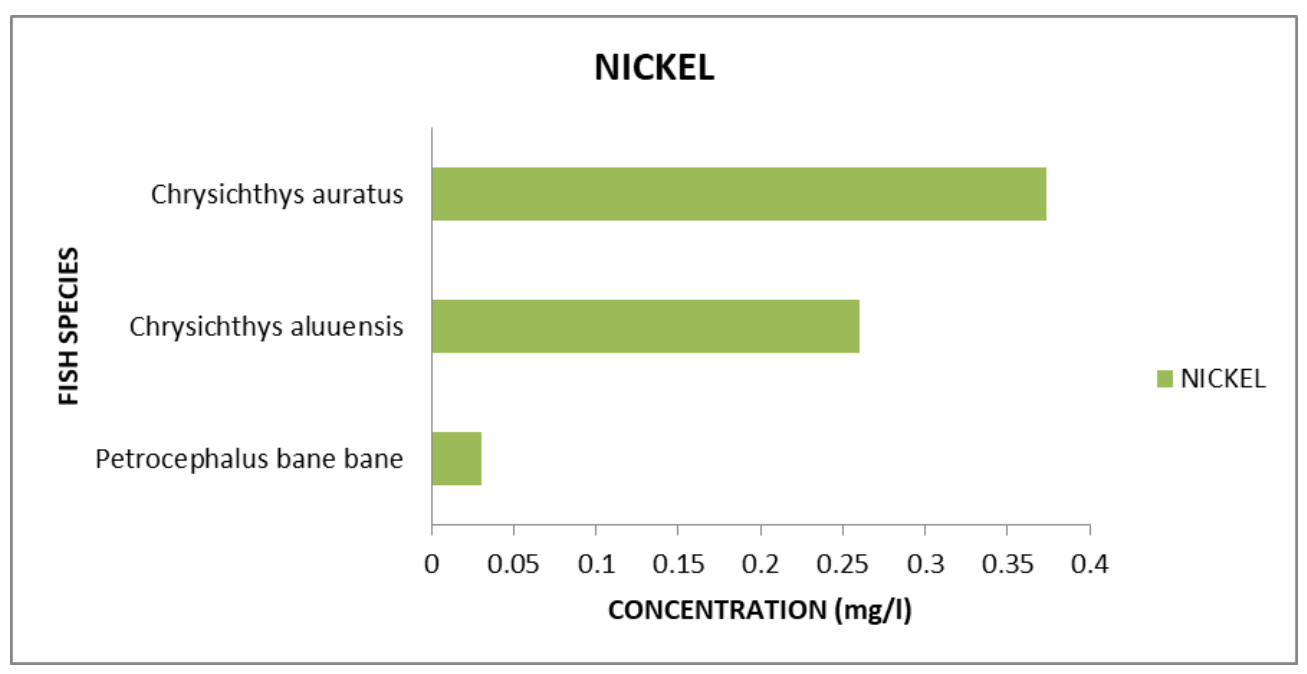

Figure 4 Nickel concentrations in different fish species

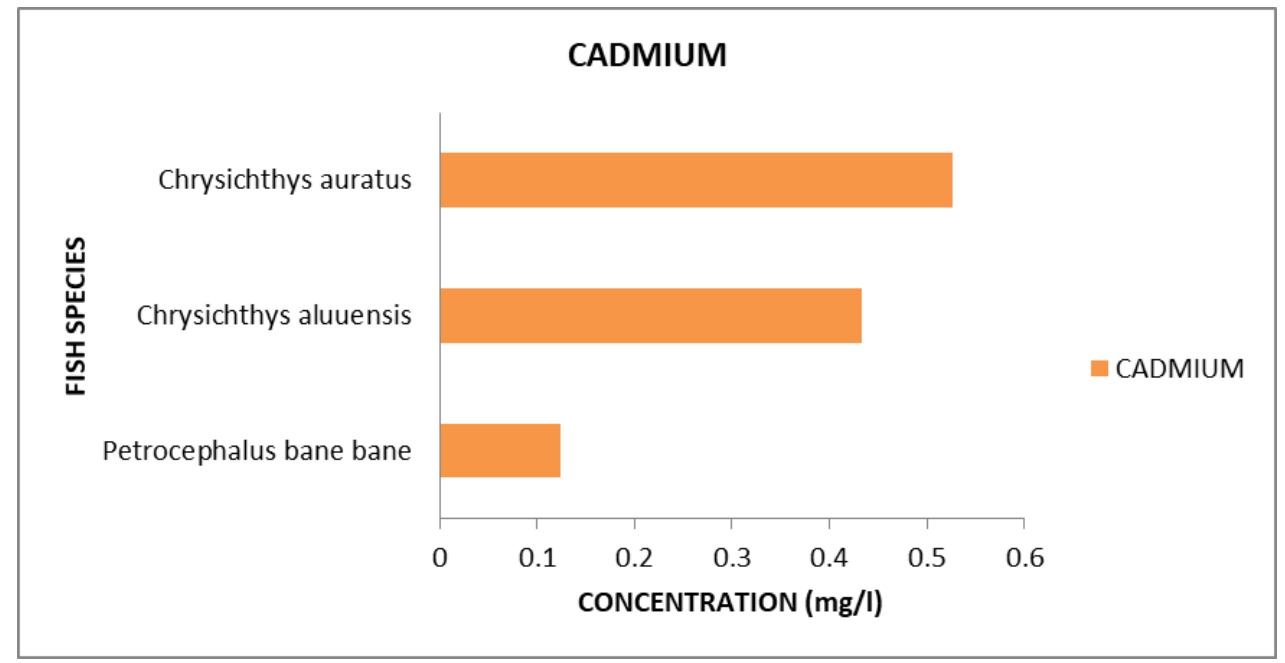

Figure 5 Cadmium concentrations in different fish species 
Table 2 The maximum permissible level of Heavy metals for fish muscle tissue

\begin{tabular}{|l|c|c|c|c|}
\hline Metal & Turkish food codex(mg/kg) & $\begin{array}{l}\text { WHO (WHO [4]) } \\
\text { (mg/kg) }\end{array}$ & $\begin{array}{c}\text { European Commission } \\
\text { (EC [5]) (mg/kg) }\end{array}$ & $\begin{array}{c}\text { FA0 FA0 [6]) } \\
\text { (mg/kg) }\end{array}$ \\
\hline $\mathrm{As}$ & - & - & - & - \\
\hline $\mathrm{Cd}$ & 0.05 & 1.00 & 0.05 & - \\
\hline $\mathrm{Co}$ & - & - & - & - \\
\hline $\mathrm{Cr}$ & - & 50 & - & - \\
\hline $\mathrm{Cu}$ & - & 30 & - & 30 \\
\hline $\mathrm{Fe}$ & - & 100 & - & - \\
\hline $\mathrm{Mn}$ & - & 1 & - & - \\
\hline $\mathrm{Ni}$ & - & $0.5-1$ & - & - \\
\hline $\mathrm{Pb}$ & 0.33 & 2.0 & 0.3 & 30 \\
\hline $\mathrm{Zn}$ & - & 100 & - & \\
\hline
\end{tabular}

In this investigation, fishes representing two different feeding habitats were studied and previous studies have demonstrated the link between high metal concentration and habitat of fish [8].

Although the findings of many scholars suggest that the accumulation of heavy metals in the flesh of fish is higher in pelagic fish than in benthic ones, the findings of this study suggest the contrary. This may be due to the fact that benthic fish, living right above the surface of the sea floor, can accumulate heavy metals from sediments, released into the water column due to environmental changes and consequently absorbed by fish as free metal ions or through fish ingestion [9].

Besides that, fishes living on the sea bottom absorb metals directly from sediments of their habitat.

The sea floor soil typically accumulates contaminants which have low water solubility. Therefore, benthic fish are more often affected by diseases related to poor water quality [10]. Furthermore, as carnivorous animals high up in the trophic levels, the prospects of bioaccumulation and biomagnification endows it with higher heavy metal levels [10].

Cd exhibited the highest rate in the different species of fishes and this was more prominent in Chrysichthys auratus. This may be due to the fact that $\mathrm{Cd}$ is not easy to be excreted once it is accumulated in the liver and body tissues [12],

The results show that the concentrations of heavy metals in the fish samples were below the permissible limit of WHO. These low concentrations may be due to the high flow of water and movement of heavy metals at the time of collection of the fish samples. This result is similar to the observation of Yi et al [13] who suggested that low concentration of heavy metals in fish may be due to high flow disturbance and downstream movement of pollutants in water.

\section{Conclusion}

The study investigated heavy concentrations in soft tissues of three pelagic and benthic fish species landed by fisher men from the river nun, at Amassoma, Bayelsa state, Nigeria. The findings reveal various metal concentrations and degree of accumulation among the different species. Among the fish species heavy metal accumulation in soft tissues followed the following trend; Chrysichthys auratus $>$ Chrysichthys aluuensis $>$ Petrocephalus bane bane. Cd is the metal with the highest metal accumulation, while the lowest metal accumulated in the tissues was Cr for Chrysichthys auratus and Chrysichthys aluuensis whereas $\mathrm{Pb}$ was the metal of lowest concentration for Petrocephalus bane bane. Statistically significant differences $(\mathrm{P}<0.05)$ were found between the amount of $\mathrm{Cd}$ determined in Petrocephalus bane bane and Chrysichthys auratus but no significant difference $(\mathrm{P}>0.05)$ between Petrocephalus bane bane and Chrysichthys aluuensis and between Chrysichthys auratus and Chrysichthys aluuensis. The order of the mean maximum metal concentrations in the muscle tissues of the fish are listed as follows; $\mathrm{Cd}>\mathrm{Ni}>\mathrm{Pb}>\mathrm{Cr}$ for Chrysichthys auratus and Chrysichthys aluuensis and $\mathrm{Cd}>\mathrm{Ni}>\mathrm{Cr}>\mathrm{Pb}$ for Petrocephalus bane bane. 
Benthic fish species accumulated more heavy metals than pelagic fishes. This was attributed to their feeding pattern as carnivores and their proximity and interphase with bottom sediments which may contain heavy metals and other contaminants. There was a preponderance of $\mathrm{Cd}$ concentration relative to other heavy metals. The presence of Cd could be as a result of indiscriminate municipal waste dumping into the river as there are no industrial plants or factories which could be indicted.

All heavy metals in fish tissues were below the international permissible limits, However, continuous and sustained consumption of fish from river nun can lead to grave health consequences due to biomagnification and bioaccumulation. Therefore, it can be concluded that Chrysichthys auratus from River nun Amassoma axis possess the highest risk to human health and safety if consumed continually as food.

\section{Compliance with ethical standards}

\section{Acknowledgments}

The Authors hereby express our gratitude to the Headship of the Department of Biological Sciences of the Niger Delta University for the privilege to use their laboratory and equipment for this research.

\section{Disclosure of conflict of interest}

All the authors hereby declare that there is no conflict of interest before, during and after the conduct of this research.

\section{References}

[1] Huang BW. Heavy Metal Concentrations in the Common Benthic Fishes Caught from the Coastal Waters of Eastern Taiwan. Journal of Food and Drug Analysis. 2003; 11: 324-330.

[2] Abdallah MAM. Trace element levels in some commercially valuable fsh species from coastal waters of Mediterranean Sea, Egypt, Journal of Marine Systems. 2008; 73(1-2): 114-122.

[3] Nweeze NO, Mahmood LB, Aisha UI. Lithological Studies and Aigal diversity, the useful fool for assessment of fish pond water quality, Asian Academic Research Journal of Mullidisplinatin Auline. 2014.

[4] WHO/FAO (World Health Organization/Food and Agriculture Organization) Codex Alimentarius Commission, General Standard for Contaminants and Toxins in Food and Feed. CODEX STAN. 2015; 193-195.

[5] EC (Commission of the European Communities). Commission regulation (EC) no 1881/2006 of 19 December 2006: setting maximum levels for certain contaminants in foodstuffs. Off. J. Eur. Union Legis. $2006 ; 364$.

[6] FAO (Food and Agriculture Organization). Compilation of legal limits for hazardous substances in fish and fishery products. FAO Fishery Circular No. 464. Food and Agriculture Organization of the United Nations. 1983; Rome.

[7] VAROL M \& SÜNBÜL MR. Biomonitoring of trace metals in the Keban Dam Reservoir (Turkey) using mussels (Unio elongatulus eucirrus) and crayfish (Astacus leptodactylus). Biol Trace Elem Res 2018; 185(1): 216-224

[8] Bawuro AA, Voegborlo RB Adimado AA. Bio-accumulation of Heavy Metals in Some Tissues of Fish in Lake Geriyo, Adamawa State, Nigeria. Journal of Environmental and Public Health Volume. 2018; Article ID 1854892, 7.

[9] Oronsaye JAO, Wangboje OM, Oguzie FA. Trace metals in some benthic fishes of the Ikpoba river dam, Benin City, Nigeria. Afr J Biotechnol. 2010; 9(51): 8860-8864.

[10] Kennish MJ. Pollution Impact on marine biotic communities. 1998; 310.

[11] Stergiou KI, Karpouzi VS. Feeding habits and trophic levels of Mediterranean fish. Rev Fish Biol Fish. 2002; $11: 217-254$.

[12] Khalid A. Seasonal determination of soil heavy metals on muscles tissues of siganus revaltus and sargus sargus fish from El-mex bay and Eastern Harbor, Alexandra, Egypt," Egyptian Journal of Aquatic Biology and Fisheries. 2004; 8 (1): 65-81.

[13] Yi Y, Yanga Z, Zhang S. Ecological risk assessment of heavy metals in sediment and human health risk assessment of heavy metals in fishes in the middle and lower reaches of the Yangtze River basin. Environmental Pollution. 2011; 159: 2575-2585. 